\title{
WHICH OLDER PEOPLE IN THE COMMUNITY HAVE THE HIGHEST CLINICAL-FUNCTIONAL VULNERABILITY?
}

\author{
Quais idosos residentes na comunidade apresentam a maior \\ vulnerabilidade clínico-funcional?
}

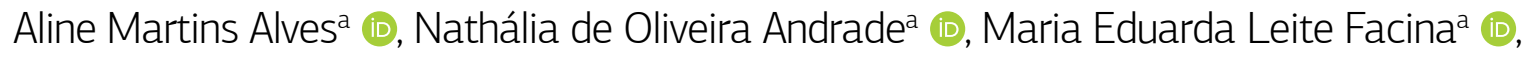 \\ Beatriz Rodrigues de Souza Melo ${ }^{\mathrm{D}}$, Aline Cristina Martins Gratão ${ }^{\mathrm{b}}$ (ㅁ), \\ Tatiana Carvalho Reis Martins ${ }^{\mathrm{a}}\left(\mathbb{D}\right.$, , Bruna Moretti Luchesia $^{\mathrm{a}}$ (1)
}

OBJECTIVE: To identify the factors related to clinical-functional vulnerability in older people. METHODS: This cross-sectional quantitative study was conducted in 2018/2019 with 492 older adults registered in Family Health Strategy units in the city of Três Lagoas, MS, Brazil. Sociodemographic data were collected and the Clinical-Functional Vulnerability Index (CFVI-20) was applied (possible score 0-40; higher scores indicate greater vulnerability). A multinomial logistic regression was performed to identify the risk factors for clinical-functional vulnerability. RESULTS: The sample's mean age was 70.80 years (SD, 7.82) and the mean CFVI-20 score was 9.25 (SD, 7.09), with $17.07 \%$ at high risk of clinical-functional vulnerability, 38.82\% at moderate risk, and $44.11 \%$ at low risk. Low education, social isolation, difficulty sleeping, and being female were risk factors for moderate vulnerability. On the other hand, low education, social isolation, difficulty sleeping, physical inactivity, being female, not using alcohol, and not participating in social groups were risk factors for high vulnerability. CONCLUSIONS: The CFVI-20 is convenient for primary health care contexts, since it is fast and easy to apply. By recognizing factors related to vulnerability, specific preventive actions can be planned.

KEYWORDS: frail elderly; primary health care; family health strategy; health vulnerability.

OBJETIVO: Identificar os fatores relacionados à vulnerabilidade clínico-funcional em idosos. METODOLOGIA: Trata-se de um estudo transversal e quantitativo, realizado em 2018/2019 com 492 idosos cadastrados em unidades com estratégia Saúde da Família (eSF) no município de Três Lagoas-MS. Foram coletados dados de caracterização sociodemográfica e se aplicou o IVCF-20 (pontuação possível de 0-40; quanto maior a pontuação, maior o risco de vulnerabilidade). Realizou-se uma regressão logística multinomial para identificar os fatores de risco para vulnerabilidade clínico-funcional. RESULTADOS: A média de idade é 70,80 \pm 7,82 anos e a média de pontuação no IVCF-20 é 9,25 \pm 7,09, sendo que 17,07\% apresentam alto risco de vulnerabilidade clínico-funcional, 38,82\% risco moderado e 44,1 1\%, baixo risco. Baixa escolaridade, isolamento social, dificuldade para dormir e sexo feminino foram fatores de risco para o risco moderado de vulnerabilidade. Já a baixa escolaridade, isolamento social, dificuldade para dormir, inatividade física, sexo feminino, não fazer uso de álcool e não participar de grupos sociais foram fatores de risco para o alto risco de vulnerabilidade. CONCLUSÕES: O IVCF-20 se mostra oportuno no contexto da atenção primária à saúde, visto que possui rápida e fácil aplicação. Com o reconhecimento dos fatores relacionados é possível planejar ações de prevenção específicas.

PALAVRAS-CHAVE: idoso fragilizado; atenção primária à saúde; estratégia saúde da família; vulnerabilidade em saúde.

aniversidade Federal de Mato Grosso do Sul - Três Lagoas (MS), Brazil.

bUniversidade Federal de São Carlos - São Carlos (SP), Brazil.

Correspondence data

Bruna Moretti Luchesi - Universidade Federal de Mato Grosso do Sul - Avenida Ranulpho Marques Leal, 3.484 - Distrito Industrial - CEP: 79613000

- Três Lagoas (MS), Brazil. E-mail: bruna_luchesi@yahoo.com.br

Received on: 12/10/2020. Accepted on: 04/27/2021

How to cite this article: Alves AM, Andrade NO, Facina MEL, Melo BRS, Gratão ACM, Martins TCR. Which older people in the community have the highest clinical-functional vulnerability? Geriatr Gerontol Aging. 2021;15:e0210031. https://doi.org/10.53886/gga.e0210031

https://doi.org/10.53886/gga.e0210031 


\section{INTRODUCTION}

With the increase in life expectancy and decrease in birth and mortality rates, there has been a rapid reorganization of the age pyramid, called the demographic transition. Although Brazil's population was mostly young in the notso-distant past, there is currently an increasingly expressive population of individuals aged 60 years or over. ${ }^{1}$

The aging process is characterized as a sequential, irreversible, cumulative and individual process of morphological, functional, biochemical and psychological changes. Thus, the population's epidemiological profile is changing, with a higher prevalence of morbidities and disabilities inherent to the aging process. In this context, a condition called frailty can emerge, which is characterized as a multi-dimensional clinical syndrome involving certain clinical manifestations that can indicate a higher degree of vulnerability to future complications, such as falls, disability and death. ${ }^{2}$

Nevertheless, the term frailty has a number of definitions; some authors ${ }^{3}$ conceptualize frailty as a decrease in homeostatic reserve or the ability to adjust to biopsychosocial aggression and, consequently, an increase in vulnerability to functional decline and its outcomes. Therefore, to better understand the aging process and its inherent care needs, a multidimensional evaluation of older adult health is necessary, considering not only chronological aspects and the presence of diseases but psychosocial aspects as well. ${ }^{3}$

Due to these circumstances, the Clinical-Functional Vulnerability Index-20 (CFVI-20) was developed and validated in Brazil. It is an interdisciplinary instrument that not only analyzes aspects of the older adult's physical health, such as age, mobility and presence of multiple comorbidities, but also evaluates activities of daily living, self-rated health, cognition, communication and mood. ${ }^{3}$ Total scores can reach 40 points, with 0-6 points indicating low risk of clinical-functional vulnerability, $7-14$ points indicating a moderate risk of clinical-functional vulnerability, and $\geq 15$ points indicating a high risk of clinical-functional vulnerability. ${ }^{3}$ The instrument was positively correlated with the Comprehensive Geriatric Assessment and has good indicators of sensitivity (90.50\%), specificity (71\%), and reliability (Cronbach's $\alpha=0.740$ and 0.861 , depending on the health service used). It is considered a good instrument for identifying older adults at risk ${ }^{3}$ as well as an innovation, since it includes psychological and social well-being as fundamental factors in the aging process.

In primary health care $(\mathrm{PHC})$, considering the many aspects of older adult health has led to effective prevention and care models, in contrast to rigid assistance standards based on fallacious stereotypes. ${ }^{4}$ The CFVI-20 is an efficient and reliable way to recognize and monitor vulnerable individuals, since it was based on the Comprehensive Geriatric Assessment, a diagnostic procedure restricted to the geriatric/gerontological team that allows global observation of older adult health. ${ }^{3}$

In addition to guaranteeing the flow of health services and preventive interventions, the CFVI-20 is also compatible with $\mathrm{PHC}$ needs because it is designed for a multiprofessional team. Unlike the Comprehensive Geriatric Assessment, the CFVI-20 can be applied by professionals other than doctors, such as nurses, nurse technicians, health community agents, etc. Furthermore, the fact that it can be applied quickly and objectively makes it favorable to the public health context. ${ }^{3}$

Therefore, the CFVI-20 can be considered an innovative multidimensional instrument, which offers a quick, economical, and effective way to globally evaluate older adults. In Brazil, PHC teams tend to consider older people frail based on their general appearance or when they present multiple diseases or comorbidities. ${ }^{3}$

Thus, this study aimed to identify factors related to clinical-functional vulnerability in community-dwelling older people to determine health-related variables that are not directly evaluated by the CFVI-20, such as sociodemographic profile, social evaluation, and life habits. We also aimed to promote healthy aging in the $\mathrm{PHC}$ context through early monitoring of the well-being and autonomy of older adults, reiterating the importance of prevention and potentializing health care access and social participation, facilitating the active aging of the population.

\section{METHODS}

This cross-sectional study, based on the quantitative investigation method, was conducted in the city of Três Lagoas, Mato Grosso do Sul, Brazil, which has a population of 10067 older adults $(9.90 \%)^{5}$ according to the latest census.

The sample consisted of older adults (aged $\geq 60$ years) treated at nine basic health units with a family health strategy, including a total of 14 health teams, which cover $41.10 \%$ of the total population. The data were collected by trained evaluators between November 2018 and November 2019 at the participants' homes or the health unit.

The sample size was based on the proportion estimate formula in a descriptive group, with categorical qualitative variables for the finite population. The significance level and sampling error were set at $5 \%(\mathrm{~d}=0.05)$, with an estimate of $50 \%(\mathrm{p}=0.50)$. Thus, a minimal sample of 371 participants was required.

The inclusion criteria were: age $\geq 60$ years, registration in one of the nine basic health units with a family health strategy, the ability to answer the questionnaire in the interviewer's 
opinion. We excluded individuals with mental disorders or untreated systemic diseases, those with uncorrected visual or hearing impairment that would prevent applying the instruments, and those who could not be found at home after two attempts at different times. Participants were recommended by the basic health unit staff, who provided a list of individuals in the coverage area meeting the inclusion criteria.

A total of 570 older people were visited; two were excluded due to change of address, 14 could not be found at home after two tries, and 62 refused to participate. The final sample consisted of 492 older adults, with an answer rate of $86.31 \%$. Participants from all nine basic health units were evaluated.

The dependent variable was clinical-functional vulnerability, which was assessed with the CFVI-20, a multidimensional assessment of older adult health. It includes 20 questions divided into eight sections: age, self-rated health, functional disabilities, cognition, mood, mobility, communication, and multiple comorbidities. Total scores vary from 0 to 40: the higher the score, the higher the risk of clinical-functional vulnerability.

The following cutoff scores were used: $0-6$ points (low risk), $7-14$ points (moderate risk) and $\geq 15$ points (high risk). ${ }^{3}$

The following independent variables were chosen because they represent important health data that is not directly evaluated by the CFVI-20:

- sociodemographic profile: sex (male/female), education (in years), family income (in multiples of the federal minimum salary) and marital status (partner/ no partner);

- social situation: number of people who reside with the participant, number of close people, participation in social groups (yes/no), and self-reported social isolation (yes/no).

- life habits: current smoker (yes/no), alcohol use (yes/ no), number of meals per day, difficulty sleeping (yes/no), and physical activity (active $=\geq 150$ minutes of moderate physical activity or 75 minutes of vigorous activity per week, according to the International Physical Activity Questionnaire - short version). ${ }^{6}$

For characterization purposes, the participants' age was also determined, since this data is collected in the CFVI-20.

The data were double entered and verified in Microsoft Excel $^{\mathrm{TM}}$ and exported to SPSS version 25.0 for analysis. Clinical-functional vulnerability was the dependent variable. Independent variables were described as mean, standard deviation (SD), and percentage, according to low, moderate, and high risk groups. Low, moderate, and high risk of clinical-functional vulnerability were estimated with 95\% confidence intervals (CI). The Pearson and Kruskal-Wallis tests were applied to compare the groups. A multinomial logistic regression was also performed to identify risk factors for clinical-functional vulnerability, using low vulnerability risk as a reference for analysis. Associations with a $\mathrm{p}$-value $\leq 0.20$ in the univariate analysis were selected for multiple analysis and were inserted in order of significance (forward stepwise selection). Variables with $\mathrm{p} \leq 0.05$ were considered significant and were included in the adjusted model.

All ethical precautions for research with human beings were taken. The project was approved by the Human Research Ethics Committee of the Universidade Federal de Mato Grosso do Sul and all participants provided written informed consent prior to inclusion.

\section{RESULTS}

The 492 participants were divided into three groups according to CFVI-20 classification, $17.07 \%$ (95\%CI 14.01-20.65) were at high clinical-functional risk, $38.82 \%$ (95\% CI 34.62 - 43.20) were at moderate risk, and $44.11 \%$ (95\%CI 39.78 -48.52) were at low risk. The mean participant age was 70.8 (SD, 7.8) years and the mean CFVI-20 score was 9.25 (SD, 7.09). Table 1 presents the independent variable data according to vulnerability risk.

Statistically significant differences were found between the three groups regarding sex, education, family income, marital status, participation in social groups, social isolation, alcohol use, number of meals per day, difficulty sleeping, and physical inactivity.

Table 2 presents the multinomial logistic regression data.

Moderate clinical-functional vulnerability was associated with the following risk factors: lower education $(\mathrm{OR}=0.94)$, social isolation $(\mathrm{OR}=1.72)$, difficulty sleeping $(\mathrm{OR}=1.95)$ and being female $(\mathrm{OR}=1.55)$. High vulnerability was associated with the following factors: lower education $(\mathrm{OR}=0.88)$, social isolation $(\mathrm{OR}=3.32)$, difficulty sleeping $(\mathrm{OR}=3.12)$, physical inactivity $(\mathrm{OR}=2.97)$, being female $(\mathrm{OR}=1.99)$, no alcohol use $(\mathrm{OR}=0.27)$, and no participation in social groups $(\mathrm{OR}=2.24)$.

\section{DISCUSSION}

In our sample, $17.07 \%$ of the participants were at high clinical-functional risk, $38.82 \%$ were at moderate risk, and $44.11 \%$ were at low risk. These data corroborate other Brazilian cross-sectional studies. In one study of 1750 older adults, $48.7 \%$ were considered at low risk, $31.2 \%$ at moderate risk, and $20.1 \%$ at high risk. ${ }^{7}$ Another study of 394 older adults 
Table 1. Characterization of the participants ( $n=492$ ) according to clinical-functional vulnerability. Três Lagoas, MS, Brazil, 2018-2019.

\begin{tabular}{|c|c|c|c|c|c|}
\hline \multirow[t]{2}{*}{ Clinical-functional vulnerability } & $\begin{array}{c}\text { Total } \\
(n=492) \\
\end{array}$ & $\begin{array}{l}\text { Low risk } \\
(n=217) \\
\end{array}$ & $\begin{array}{l}\text { Moderate risk } \\
(\mathrm{n}=191)\end{array}$ & $\begin{array}{l}\text { High risk } \\
(n=84)\end{array}$ & \multirow[t]{2}{*}{ p-value* } \\
\hline & \multicolumn{4}{|c|}{$\%$ or average (standard deviation) } & \\
\hline \multicolumn{5}{|l|}{ Sex } & 0.001 \\
\hline Male & 39.84 & 48.85 & 35.08 & 27.38 & \multirow{3}{*}{0.001} \\
\hline Female & 60.16 & 51.15 & 64.92 & 72.62 & \\
\hline Education (years) & 4.06 (3.99) & $4.82(4.34)$ & $3.71(3.88)$ & $2.88(2.78)$ & \\
\hline \multicolumn{6}{|l|}{ Family income } \\
\hline$\leq 2 \times$ the federal minimum salary & 53.86 & 50.69 & 62.83 & 41.67 & \multirow{3}{*}{0.002} \\
\hline$>2 \times$ the federal minimum salary & 36.18 & 41.02 & 28.79 & 40.48 & \\
\hline Not disclosed & 9.96 & 8.29 & 8.38 & 17.86 & \\
\hline \multicolumn{6}{|l|}{ Marital status } \\
\hline Partner & 50.00 & 56.22 & 49.21 & 35.71 & \multirow{2}{*}{0.006} \\
\hline No partner & 50.00 & 43.78 & 50.78 & 64.29 & \\
\hline Number of people in the home & $2.68(1.52)$ & $2.70(1.44)$ & $2.57(1.57)$ & $2.89(1.57)$ & 0.062 \\
\hline Number of close people & $6.26(12.04)$ & $6.14(9.36)$ & $5.57(7.13)$ & $8.13(22.52)$ & 0.886 \\
\hline Participation in social groups (no) & 30.69 & 27.19 & 29.84 & 41.67 & 0.048 \\
\hline Social isolation (yes) & 25.61 & 16.13 & 27.75 & 45.24 & $<0.001$ \\
\hline Smoking (yes) & 11.39 & 10.60 & 10.99 & 14.29 & 0.650 \\
\hline Alcohol use (yes) & 17.48 & 21.69 & 17.80 & 5.95 & 0.006 \\
\hline Meals/day & $3.44(1.15)$ & $3.52(1.04)$ & $3.50(1.27)$ & $3.12(1.08)$ & 0.006 \\
\hline Difficulty sleeping (yes) & 38.82 & 26.73 & 43.98 & 58.33 & $<0.001$ \\
\hline Physical inactivity (yes) & 65.04 & 60.18 & 63.35 & 82.14 & 0.001 \\
\hline
\end{tabular}

*Pearson or Kruskal-Wallis tests.

Table 2. Multinomial logistic regression analysis of the risk factors for clinical-functional vulnerability in older adults $(\mathrm{n}=$ 492). Três Lagoas, MS, Brazil, 2018-2019.

\begin{tabular}{|c|c|c|c|c|}
\hline \multirow{3}{*}{ Clinical-functional vulnerability } & Univariate & Multivariate & Univariate & Multivariate \\
\hline & OR $(95 \% \mathrm{Cl})$ & OR $(95 \% \mathrm{Cl})$ & OR $(95 \% \mathrm{Cl})$ & OR $(95 \% \mathrm{Cl})$ \\
\hline & \multicolumn{2}{|c|}{ Moderate risk } & \multicolumn{2}{|c|}{ High risk } \\
\hline Education & $0.93(0.89-0.98)$ & $0.94(0.89-0.98)^{*}$ & $0.86(0.80-0.94)$ & $0.88(0.80-0.95)^{*}$ \\
\hline Social isolation (yes) & $2.00(1.24-3.23)$ & $1.72(1.04-2.83)^{*}$ & $4.30(2.45-7.53)$ & $3.32(1.79-6.15)^{*}$ \\
\hline Difficulty sleeping (yes) & $2.15(1.42-3.26)$ & $1.95(1.27-3.01)^{*}$ & $3.84(2.26-6.51)$ & $3.12(1.74-5.59)^{*}$ \\
\hline Physical inactivity (yes) & $1.14(0.77-1.71)$ & $1.17(0.77-1.77)$ & $3.04(1.64-5.66)$ & $2.97(1.52-5.79)^{*}$ \\
\hline Sex (female) & $1.77(1.19-2.63)$ & $1.55(1.02-2.38)^{*}$ & $2.53(1.46-4.38)$ & $1.99(1.07-3.68)^{*}$ \\
\hline Alcohol use (yes) & $0.78(0.48-1.28)$ & $0.89(0.52-1.51)$ & $0.23(0.09-0.60)$ & $0.27(0.10-0.75)^{*}$ \\
\hline Participation in social groups (no) & $1.14(0.74-1.75)$ & $1.28(0.81-2.03)$ & $1.91(1.13-3.24)$ & $2.24(1.23-4.08)^{*}$ \\
\hline
\end{tabular}

OR: odds ratio; 95\%Cl: 95\% confidence interval; * $\mathrm{p} \leq 0.05$. 
found that $19.5 \%$ were at high risk, $28 \%$ at moderate risk, and $52.5 \%$ at low risk. ${ }^{8}$ Silva et al. ${ }^{9}$ found that $71.8 \%$ of their sample of older adults were at low risk, $22 \%$ at moderate risk and $6.2 \%$ at high risk.

Low education is a risk factor for moderate risk. This correlation might be justified by the protective effect of education on older adult cognition, as was found in a cross-sectional study conducted in Curitiba, PR, Brazil. ${ }^{10}$ Furthermore, older adults with lower education have low access to information, which results in more unhealthy life habits and low preventive use of health services, considering that literacy can facilitate the inclusion of older adults in health promotion actions, as concluded by the FIBRA Study, which was carried out in 17 Brazilian cities. ${ }^{11}$ Similarly, an Italian study found a relationship between frailty and low education. ${ }^{12}$ Furthermore, a relationship between education and physical function in older adults has also been found in high-income countries, such as England. ${ }^{13}$ This social determinant increases vulnerability, impacting the frailty process in older adults. ${ }^{14}$

Corroborating the literature, ${ }^{11,15-17}$ there was a relationship between higher risk and difficulty sleeping. It is known that effective sleep is directly related to quality of life. ${ }^{18}$ However, difficulty sleeping is an avoidable part of aging. Sleep complaints are usually related to other morbidities, such as joint disease and urinary incontinence, as well as to being female. ${ }^{19}$ Poor sleep quality impedes activities of daily living and damages cognition and mental health, affecting the well-being of older adults. ${ }^{11,16}$

Social isolation is an increasingly common phenomenon in contemporary society. Loneliness can be related to life satisfaction, including thoughts about lack of support. ${ }^{20}$ Studies have shown that loneliness is related to depression, lower quality of life, ${ }^{21-24}$ and greater vulnerability to physical and mental health problems in older individuals. ${ }^{24-26} \mathrm{~A}$ Finnish study found strong evidence that social isolation has an adverse effect on mortality. ${ }^{27}$ The present study also found that self-reported social isolation is linked to higher risk of vulnerability.

One factor that can explain the relationship between being female and having a moderate or high risk of vulnerability is the higher prevalence of sarcopenia in women, which was demonstrated in the SarcoPhAge studyin Belgium ${ }^{28}$, as well as in the Hertfordshire Cohort Study in the United Kingdom. ${ }^{29}$ Sarcopenia has a direct tie with frailty, since both conditions share common biological pathways and inflammatory markers. ${ }^{30}$ The development of frailty in women is also influenced by various hormonal deficiencies and increased inflammatory states. ${ }^{31}$ Furthermore, social aspects play a relevant role in the higher vulnerability of women. In the city of São Paulo, it was observed that men under 75 years of age had greater access to health care than women, as well as that dependent older women are more frequently widows and, consequently, do not have a spousal caregiver. ${ }^{32}$ An Ethiopian study found that women perform significantly more tasks and have greater responsibilities than men, resulting in a greater burden and less rest. ${ }^{33}$ Although women live longer than men, they tend to have worse health. For them the environment is more harmful, even in developed countries, and lifestyle factors increase vulnerability to subcellular mechanisms that prolong recovery time. ${ }^{34}$ Thus, the results of the present study corroborate studies that have found a higher prevalence of frailty in women. ${ }^{35,36}$

An association between vulnerability and physical inactivity was found in a longitudinal study conducted in Bahia, Brazil. ${ }^{37}$ According to this study, frailty is related to $<150$ minutes of physical activity per week and $\geq 540$ minutes of sedentary behavior per day. A cross-sectional study of Chinese adults $\geq 50$ years of age found a linear dosage-response curve between daily sedentary time and frailty. ${ }^{38}$ Furthermore, a Korean cohort study concluded that physical activity is negatively associated with mortality from cardiovascular, mental, and respiratory diseases and cancer. ${ }^{39}$ It has also been found that exchanging 30 minutes of physical inactivity with an equal period of light physical activity reduces the risk of frailty in older adults. ${ }^{40}$

Our results indicate that individuals who do not consume alcohol have a higher risk of vulnerability, which agrees with other research, such as a Danish study ${ }^{41}$ that found an association between light to moderate alcohol consumption and a lower risk of coronary heart disease in both men and women. According to a U.S. study, ${ }^{42}$ consuming small amounts of alcoholic beverages is a protective factor against ischemia. However, one limitation of the present study was that we collected no information regarding the amount or frequency of alcohol consumption. Thus, the relationship between vulnerability and alcohol consumption should be investigated in future studies.

Regarding participation in social groups, older adults who do not do so have higher vulnerability. A study on older adults in Paraíba, Brazil found that participating in social groups signifies a return to social living. ${ }^{43}$ The benefits these authors cited include reduced loneliness, leisure activity, physical activity, social living, a feeling of freedom, the will to live, and improved quality of life ${ }^{43}$. Furthermore, a positive correlation was found between feelings of loneliness and depression and anxiety symptoms in an in Egyptian study. ${ }^{44}$

\section{CONCLUSION}

The risk factors for clinical-functional vulnerability in the community's older adults include low education, 
social isolation, difficulty sleeping, physical inactivity, being female, not consuming alcohol, and not participating in social groups. More than half of the older adults in our study had high or moderate risk of clinical-functional vulnerability.

In developing countries such as Brazil, especially in the state of Mato Grosso do Sul, clinical-functional vulnerability in older adults is not well studied. It has been observed that the aging process appears in unfavorable health, economic, and social conditions, which might explain the high prevalence of clinical-functional vulnerability in the population. These results can help direct older adult care in PHCs, including procedural guidelines and improvements in practice and decision-making by professional teams, which should consider the whole biopsychosocial individual. One feasible idea is periodic multidimensional evaluations by a multi-professional team, which could prevent clinical-functional vulnerability and reduce adverse outcomes, such as institutionalization, hospitalization, and morbidity and mortality rates. In the Unified Health System, which uses PHC as a reference, these actions could contribute to integrated care and active aging of the population.

\section{CONFLICT OF INTERESTS}

The authors declare no conflicts of interest.

\section{FUNDING}

This study was supported by the Universidade Federal de Mato Grosso do Sul (Edital PROPP/UFMS 40/2020 Mulheres na Ciência - auxílio para tradução and EDITAL PROPP/UFMS 30/2019 - Bolsa de iniciação científica) and the Coordenação de Aperfeiçoamento de Pessoal de Nível Superior - Finance Code 001.

\section{AUTHOR CONTRIBUTIONS}

AMA: data curation, writing - original draft. NOA: data curation, writing - original draft. MELF: data curation, writing - original draft. BRSM: data curation, project administration, writing - review \& editing. ACMG: Project administration, writing - review \& editing. TCRM: conceptualization, supervision, writing - review \& editing. BML: conceptualization, formal analysis, supervision, writing - review \& editing.

\section{REFERENCES}

1. Miranda GMD, Mendes ACG, Silva ALA. Envelhecimento populacional no Brasil: desafios e consequências sociais atuais e futuras. Rev Bras Geriatr Gerontol. 2016;19(3):507-19. http://dx.doi.org/10.1590/180998232016019.150140

2. Lana LD, Schneider RH. Síndrome de fragilidade no idoso: uma revisão narrativa. Rev Bras Geriatr Gerontol. 2014;17(3):673-80. http://dx.doi.org/10.1590/1809-9823.2014.12162

3. Moraes EM, Carmo JA, Moraes FL, Azevedo RS, Machado CJ, Montilla DER. Índice de Vulnerabilidade Clínico Funcional-20 (IVCF-20): reconhecimento rápido do idoso frágil. Rev Saúde Pública. 2016;50:81. http://dx.doi.org/10.1590/s1518-8787.2016050006963

4. Saraiva LB, Santos SNSA, Oliveira FA, Almeida ANS, Moura DJM, Barbosa RGB. Avaliação Geriátrica Ampla e sua Utilização no Cuidado de Enfermagem a Pessoas Idosas. J Heal Sci. 2017;19(4):262-7. https://doi.org/10.17921/2447-8938.2017v19n4p262-267

5. Instituto Brasileiro de Geografia e Estatística. Censo demográfico 2010. Características da população e dos domicílios: resultados do universo. Rio de Janeiro: Instituto Brasileiro de Geografia e Estatística; 2011.

6. Benedetti TRB, Antunes PC, Rodríguez-Añez CR, Mazo GZ, Petroski EL. Reproducibility and validity of the International Physical Activity Questionnaire (IPAQ) in elderly men. Rev Bras Med Esporte. 2007;13(1):11-6. http://dx.doi.org/10.1590/S151786922007000100004

7. Maia LC, Colares TFB, Moraes EN, Costa SM, Caldeira AP. Idosos robustos na atenção primária: fatores associados ao envelhecimento bem-sucedido. Rev Saúde Publica. 2020;54:35. http://dx.doi. org/10.11606/s1518-8787.2020054001735

8. Carneiro JA, Souza ASO, Maia LC, Costa FM, Moraes EN, Caldeira AP. Fragilidade em idosos comunitários: comparando instrumentos de triagem. Rev Saúde Pública. 2020;54:119. http://dx.doi.org/10.11606/ s1518-8787.2020054002114
9. Silva JNMA, Leite MT, Gaviraghi LC, Kirsten VR, Kinalski SS, Hildebrandt LM, et al. Dimensões preditoras das condições clínico-funcionais e cognição em idosos. Rev Bras Enferm. 2020;73(Supl. 3):e20190162. http://dx.doi.org/10.1590/0034-7167-2019-0162

10. Lenardt MH, Carneiro NHK, Binotto MA, Setoguchi LS, Cechinel C. Relação entre fragilidade física e características sociodemográficas e clínicas de idosos. Esc Anna Nery. 2015;19(4):585-92. http://dx.doi. org/10.5935/1414-8145.20150078

11. Santos AA, Mansano-Schlosser TCS, Ceolim MF, Pavarini SCI. Sono, fragilidade e cognição: estudo multicêntrico com idosos brasileiros. Rev Bras Enferm. 2013;66(3):351-7. http://dx.doi.org/10.1590/ S0034-71672013000300008

12. Liotta G, O'Caoimh R, Gilardi F, Proietti MG, Rocco G, Alvaro R, et al. Assessment of frailty in community-dwelling older adults residents in the Lazio region (Italy): A model to plan regional community-based services. Arch Gerontol Geriatr. 2017;68:1-7. http://doi.org/10.1016/j. archger.2016.08.004

13. Lima-Costa MF, Oliveira C, Macinko J, Marmot M. Socioeconomic Inequalities in Health in Older Adults in Brazil and England. Am J Public Health. 2012;102(8):1535-41. http://doi.org/10.2105/ AJPH.2012.300765

14. Francisco PMSB, Marques PP, Borim FSA, Torres SF, Neri AL. Disability relating to instrumental activities of daily living in the elderly with rheumatic diseases. Rev Bras Geriatr Gerontol. 2018;21(5):570-8. https://doi.org/10.1590/198122562018021.180089

15. Santos AA, Ceolim MF, Neri AL. Queixas de sono em idosos brasileiros de municípios com diferentes Indices de Desenvolvimento Humano. Rev Latino-Am Enfermagem. 2012;20(5):917-26. https://doi. org/10.1590/S0104-11692012000500014

16. Miner B, Kryger MH. Sleep in the Aging Population. Sleep Med Clin. 2017;12(1):31-8. http://doi.org/10.1016/j.jsmc.2016.10.008 
17. Cochen V, Arbus C, Soto ME, Villars H, Tiberge M, Montemayor T, et al. Sleep disorders and their impacts on healthy, dependent, and frail older adults. J Nutr Health Aging. 2009;13(4):322-9. http://doi. org/10.1007/s12603-009-0030-0

18. Li N, Xu G, Chen G, Zheng X. Sleep quality among Chinese elderly people: A population-based study. Arch Gerontol Geriatr. 2020;87:103968. http://dx.doi.org/10.1016/j.archger.2019.103968

19. Moreno CRC, Santos JLF, Lebrão ML, Ulhôa MA, Duarte YAO. Problemas de sono em idosos estão associados a sexo feminino, dor e incontinência urinária. Rev Bras Epidemiol. 2018;21(Supl. 2):e180018. https://doi.org/10.1590/1980-549720180018.supl.2

20. Azeredo ZAS, Afonso MAN. Solidão na perspectiva do idoso. Rev Bras Geriatr Gerontol. 2016;19(2):313-24. http://dx.doi.org/10.1590/180998232016019.150085

21. Mellor D, Stokes M, Firth L, Hayashi Y, Cummins R. Need for belonging, relationship satisfaction, loneliness, and life satisfaction. Pers Individ Dif. 2008;45(3):213-8. https://doi.org/10.1016/j.paid.2008.03.020

22. Isik K, Başoğul C, Yildirim H. The relationship between perceived loneliness and depression in the elderly and influencing factors. Perspect Psychiatr Care. 2021;57:351-7. https://doi.org/10.1111/ ppc. 12572

23. Domènech-Abella J, Lara E, Rubio-Valera M, Olaya B, Moneta MV, Rico-Uribe LA, et al. Loneliness and depression in the elderly: the role of social network. Soc Psychiatry Psychiatr Epidemiol. 2017;52:38190. https://doi.org/10.1007/s00127-017-1339-3

24. Lim LL, Kua E-H. Living alone, loneliness and psychological wellbeing of older persons in Singapore. Curr Gerontol Geriatr Res. 2011:673181. https://doi.org/10.1155/2011/673181

25. Richard A, Rohrmann S, Vandeleur CL, Schmid M, Barth J, Eichholzer M. Loneliness is adversely associated with physical and mental health and lifestyle factors: Results from a Swiss national survey. PLoS One. 2017;12(7):e0181442. https://doi.org/10.1371/journal. pone.0181442

26. Crewdson JA. The Effect of Loneliness in the Elderly Population: A Review. Healthy Aging Clin Care Elderly. 2016;8:1-8. https://doi. org/10.4137/HACCE.S35890

27. Tanskanen J, Anttila T. A Prospective Study of Social Isolation, Loneliness, and Mortality in Finland. Am J Public Health. 2016;106(11):2042-8. https://doi.org/10.2105/AJPH.2016.303431

28. Beaudart C, Reginster JY, Petermans J, Gillain S, Quabron A, Locquet $M$, et al. Quality of life and physical components linked to sarcopenia: The SarcoPhAge study. Exp Gerontol. 2015;69:103-10. https://doi. org/10.1016/j.exger.2015.05.003

29. Patel HP, Syddall HE, Jameson K, Robinson S, Denison H, Roberts $\mathrm{HC}$, et al. Prevalence of sarcopenia in community-dwelling older people in the UK using the European Working Group on Sarcopenia in Older People (EWGSOP) definition: findings from the Hertfordshire Cohort Study (HCS). Age Ageing. 2013;42(3):378-84. https://doi. org/10.1093/ageing/afs197

30. Pillatt AP, Patias RS, Berlezi EM, Schneider RH. Quais fatores estão associados à sarcopenia e à fragilidade em idosos residentes na comunidade? Rev Bras Geriatr Gerontol. 2018;21(6):781-92. https:// doi.org/10.1590/1981-22562018021.180165

31. Eichholzer M, Richard A, Walser-Domjan E, Linseisen J, Rohrmann S. Urinary phytoestrogen levels and frailty in older American women of the National Health and Nutrition Examination Survey (NHANES) 1999-2002: a cross-sectional study. Ann Nutr Metab. 2013;63(4):269-76. https://doi.org/10.1159/000356453

32. Camarano AA, Mello JL. Cuidados de longa duração para a população idosa: um novo risco social a ser assumido? Rio de Janeiro: Ipea; 2010.

33. Dessalegn M, Ayele M, Hailu Y, Addisu G, Abebe S, Solomon H, et al. Gender Inequality and the Sexual and Reproductive Health Status of Young and Older Women in the Afar Region of Ethiopia. Int J Environ Res Public Health. 2020;17(12):4592. https://doi.org/10.3390/ ijerph17124592

34. Hubbard RE. Sex Differences in Frailty. Interdiscip Top Geronto Geriatr. 2015;41:41-53. https://doi.org/10.1159/000381161

35. Zhang Q, Guo H, Gu H, Zhao X. Gender-associated factors for frailty and their impact on hospitalization and mortality among communitydwelling older adults: a cross-sectional population-based study Peer). 2018;6:e4326. https://doi.org/10.7717/peerj.4326

36. Ma L, Tang Z, Zhang L, Sun F, Li Y, Chan P. Prevalence of Frailty and Associated Factors in the Community-Dwelling Population of China. J Am Geriatr Soc. 2018;66(3):559-564. https://doi.org/10.1111/ jgs. 15214

37. Silva VD, Tribess S, Meneguci J, Sasaki JE, Garcia-Meneguci CA Carneiro JAO, et al. Association between frailty and the combination of physical activity level and sedentary behavior in older adults. BMC Public Health. 2019;19(1):709. https://doi.org/10.1186/s12889-0197062-0

38. Guo YF, Shi Y, Ruan Y, Sun SY, Huang ZZ, Zheng Y, et al. Association between daily sedentary time and frailty among people aged 50 years and over. Zhonghua Liu Xing Bing Xue Za Zhi. 2019;40(10):1257-61 https://doi.org/10.3760/cma.j.issn.0254-6450.2019.10.016

39. Min C, Yoo DM, Wee JH, Lee H, Byun SH, Choi HG. Mortality and cause of death in physical activity and insufficient physical activity participants: a longitudinal follow-up study using a national health screening cohort. BMC Public Health. 2020;20:1469. https://doi. org/10.1186/s12889-020-09564-x

40. Nagai K, Tamaki K, Kusunoki H, Wada Y, Tsuji S, Ito M, et al Isotemporal substitution of sedentary time with physical activity and its associations with frailty status. Clin Interv Aging. 2018;13:1831-6. https://doi.org/10.2147/CIA.S175666

41. Tolstrup J, Jensen MK, Tjønneland A, Overvad K, Mukamal KJ, Grønbæk M. Prospective study of alcohol drinking patterns and coronary heart disease in women and men. BMJ. 2006;332:1244. https:// doi.org/10.1136/bmj.38831.503113.7C

42. Elkind MSV, Sciacca R, Boden-Albala B, Rundek T, Paik MC, Sacco $\mathrm{RL}$. Moderate alcohol consumption reduces risk of ischemic stroke. Stroke. 2006;37(1):13-9. https://doi.org/10.1161/01. STR.0000195048.86810.5b

43. Andrade NA, Nascimento MMP, Oliveira MMD, Queiroga RM, Fonseca FLA, Lacerda SNB, et al. Percepção de idosos sobre grupo de convivência: estudo na cidade de Cajazeiras-PB. Rev Bras Geriatr Gerontol. 2014;17(1):39-48. https://doi.org/10.1590/ S1809-98232014000100005

44. Ahmed D, El Shair IH, Taher E, Zyada F. Prevalence and predictors of depression and anxiety among the elderly population living in geriatric homes in Cairo, Egypt. J Egypt Public Health Assoc. 2014;89(3):12735. https://doi.org/10.1097/01.epx.0000455729.66131.49 